Article

\title{
Game-Based Learning for Green Building Education
}

\section{Yi-Kai Juan and Tseng-Wei Chao *}

Department of Architecture, National Taiwan University of Science and Technology, 43 Section 4, Keelung Road, 106 Taipei, Taiwan; E-Mail: rik@mail.ntust.edu.tw

* Author to whom correspondence should be addressed; E-Mail: d9913009@mail.ntust.edu.tw; Tel.: +886-9-55-800-688; Fax: +886-2-2737-6721.

Academic Editor: Marc A. Rosen

Received: 12 March 2015 / Accepted: 4 May 2015 / Published: 7 May 2015

\begin{abstract}
To improve education regarding sustainability and green buildings, we designed a multiplayer (2-4 people) green building strategy game called GBGame to deliver knowledge of and introduce applied technologies for green buildings. To verify the game's learning effect, we conducted separate measurements using the ARCS motivation model and a paper-based exam among 72 students majoring in architecture. These students were divided into an experimental group (who played the game) and a control group (who underwent lecture-based instruction). Results indicate that (1) game players had stronger learning motivation than those who attended the lectures; (2) players who learned through the game generally exhibited better learning effectiveness than non-players; (3) following cross-validation, we discovered a highly significant correlation between the learning effect and players' attention, perception of relevance, confidence, and satisfaction during the game; and (4) the game system was found to be attractive to the students, implying that it can be an effective instructional and recreational material to use during green building education.
\end{abstract}

Keywords: green buildings; game-based learning; ARCS motivation model; Instructional Materials Motivation Survey (IMMS)

\section{Introduction}

The world is facing rapid and inevitable urbanization [1,2]. Every year, cities are expanding at a rate of $9 \%$, while agricultural areas and forests are decreasing at a rate of $2.4 \%$ [3]. Studies have indicated that cities' carbon dioxide emissions account for $80 \%$ of the global total [3], and the energy 
consumed by the building industry globally accounts for $40 \%$ of total energy consumption [4]. Therefore, when faced with rapid urbanization and attendant environmental change, governments and educators in various countries will likely devote increased attention to engaging in greener development [5].

Green building is building design that improves the efficiency of resources used such as energy (e.g., electricity), water, and materials, while simultaneously reducing the impact of a building on human health and the environment [6]. In 1990, the Building Research Establishment in the UK developed the world's first green building assessment system, the Building Research Establishment Environmental Assessment Method (BREEAM). The system was initially used only for the assessment of newly constructed office buildings but was eventually applied to various types of buildings to assist designers in their initial planning and design phases [7]. Following the development of the BREEAM, a growing number of other countries have also developed their own green building assessment systems, such as the Leadership in Energy and Environmental Design (LEED) assessment method developed by the U.S. Green Building Council and Canada's GB Tool System [8]. In all, there are currently 26 green building assessment systems worldwide [9]. In the structure of these assessment systems, most rating tools are focused on the life cycle assessment covering the stages of programming, design, construction, and operation. In addition, all of these assessment items include the issues of water and energy efficiency, materials and resources, and indoor environmental quality [10]. These systems are used as important communication tools to enhance dialogue between different design team members and broader groups of stakeholders [11], and are enablers to push the increasing number of owners and developers to realize the market value and potential of green buildings [10]. The estimated value of the global green building market, for instance, was $\$ 195$ billion in 2010 and is anticipated to reach $\$ 600$ billion by 2015 [12].

Taiwan established a scientific, quantitative Green Building Labeling System in 1999, which was the first assessment system suitable for tropical and subtropical regions. It consists of nine indicators, covering (1) biodiversity; (2) greening; (3) water soil content; (4) daily energy savings; (5) carbon dioxide emission reduction; (6) solid waste reduction; (7) water resources; (8) sewage and waste improvement; and (9) indoor health and environmental health [13]. By the end of March 2013, a total of 3753 buildings or building projects were certified as green buildings; water and electricity bill savings can reach $\$ 100$ million annually [14]. Although the importance of environmental awareness has gained attention among the general public and governments, promoting green buildings has faced several obstacles [9]. Studies have indicated that people's willingness to accept green buildings was generally low because they did not fully understand the benefits, which had not been clearly conveyed [15]. This led to wariness about green building, especially since the construction costs are relatively high - environmentally friendly and energy-efficient equipment and facilities are more expensive than traditional materials. In addition, in many customer-oriented property markets such as East Asian countries, the willingness of construction companies to invest in green buildings has often been low because customers are not inclined to purchase a built product with high initial costs [9]. Therefore, there is still considerable room for improvement in the promotion of green building concepts and the public's awareness of environmental conservation [16].

Several academic studies on green building have emphasized technical aspects such as the application of solar thermal technology [17]; various design aspects [18,19]; marketability (e.g., 
people's level of willingness to purchase or fund green buildings) [20]; environmental assessment systems and tools [21,22]; and green building policies and promotions [23,24]. In contrast, issues relating to strengthening people's understanding of green buildings and environmental education have rarely been discussed. In recent years, there has been a growing trend toward the use of games as a teaching method. Previous studies have revealed that the application of games in various practical teaching fields has achieved positive results [25-27]; for example, using games as a teaching medium has been shown to make the learning process more enjoyable, which in turn makes learners receptive to the learning content [27]. The game process is also a self-regulated learning model, meaning that it promotes individual cognitive development more effectively than traditional lecture-based learning [28].

This study presents the development and testing of a tabletop game with a green building theme into which the nine indicators of the Green Building Labeling System (Taiwan) will be integrated to help players understand the concept of "environmental awareness." Seventy-two higher vocational school students majoring in architecture, divided into a control group and an experimental group, were used as experimental subjects to verify the learning effectiveness of the game. The next section will introduce the history of, concepts pertaining to, and literature related to game-based learning; subsequent sections will cover learning motivation and learning effectiveness, the design of this study's experiment, its results, and some conclusions and discussion for the application of the research.

\section{Overview of Game-Based Learning}

Games have always played an important role in human life; not only for entertainment, but also in fields such as education [29]. Using games as a teaching medium makes the learning process more enjoyable, which in turn makes the learners more receptive to the messages or information the game's creator or the instructor intends to convey [27].

Among the different types of games, tabletop games in particular are an observed human practice that goes back to around 3000 BCE in pre-dynastic Egypt, where they played an important role in society [30]. Tabletop games are easy to transport, easy to learn, environmentally friendly, and cheap to produce; further, they foster easy communication and transmission of knowledge or skills [30]. Tabletop games have been used on many topics in the architecture, engineering, and construction (AEC) industry, including simulation of the building tender process [25], urban sustainable development learning [27], energy simulation [16], interdisciplinary communication and education for climate change [31], and construction resource allocation practices [32]. These examples show that tabletop games can be applied widely to education and can simulate various scenarios. In recent years, tabletop games with environment-focused themes have started to emerge, such as the game Meltdown launched by the German science magazine GEOlino, which addresses the problem of rapid ice melt at the North Pole as a result of global warming. In the game, "ice blocks" are used to simulate ice layers so that players can visualize this disaster caused by the greenhouse effect [33]. Another game, called EnviroPoly, aims to educate players on daily behaviors that may damage the environment and how to avoid them. The game includes 51 cards explaining environmental issues that are read during the game to educate the players [34]. 


\section{ARCS Motivation Model and Instructional Materials Motivation Survey}

In many Asian countries, traditional rote-learning education systems, which resulted in part from a strong emphasis on credentialism, are the focus of severe disputes. In the lecture-based teaching mode, where a teacher presents formal lectures and students passively take notes for learning, students more often lack independent thinking ability and learning motivation than under systems that promote more independent thought and interaction [35]. In educational psychology, motivation is often regarded as the critical factor for either the success or failure of learning [36]. Lack of learning motivation affects the learner's attention in class, which in turn affects the quality of education [37]. In this sense, learning motivation is inseparable from learning effectiveness: greater motivation improves learning results and encourages learners to make a greater effort and continue learning [38]. Hofer [39] indicated that teachers should understand how to stimulate students' learning motivation to improve teaching effectiveness. This implies, among other things, that if instructional material does not stimulate learners' attention or interest, the effectiveness of learning suffers major setbacks [38]. Conversely, motivation is capable of stimulating a desire for learning and facilitating the completion of learning activities [40].

Given this inseparable relationship between motivation and education, teachers are faced with the need to identify strategies that will improve students' learning motivation [41]. In pursuit of this goal, Keller [38] proposed a systematic teaching strategy capable of improving and maintaining learning motivation, known as the ARCS motivation model, which identifies the following as the four essential factors of learning motivation:

(1) Attention: This refers to whether teaching methods and instructional materials used can attract and retain learners' attention and interest and stimulate their curiosity.

(2) Relevance: This refers to the potential for the application of courses and instructional materials. Teachers must meet learners' individual requirements and goals to elicit an active learning attitude; similarly, to feel that materials are relevant, learners must be able to identify the significance of the learning. If applicability is not achieved, even if the learner's attention is attracted, effective learning will not be maintained [42].

(3) Confidence: Confidence affects learning endurance and achievement by either fostering or hindering motivation. If teachers neglect learners' apprehensions that the course may be either too difficult or not challenging enough, learners may lose confidence and thus motivation, hindering their learning. Therefore, instructional materials should be of an appropriate level of difficulty.

(4) Satisfaction: This refers to learners' evaluation of the results of their work, and is an important factor for maintaining motivation. Learning is satisfactory when learners can apply learned knowledge or skills for a practical purpose (in this case, environmental protection through green building) that ultimately leads to a feeling of satisfaction [43].

The ARCS motivation model can provide systematic teaching criteria to ensure that course design and instructional materials reflect learners' characteristics and meet their needs [44]. Following the development of Keller's ARCS motivation model, the Instructional Materials Motivation Survey (IMMS) was developed to verify a learner's degree of motivation. The IMMS uses 36 questions answered on a five-point Likert-type scale to measure the motivational reactions of learners 
( 1 = Strongly disagree, $2=$ Disagree, $3=$ Neutral, $4=$ Agree, and $5=$ Strongly agree $)$, for a total score that can range from 36 to 180 [45]. The IMMS measures motivational elements of instruction materials, whereby learning motivation can be understood [43].

This study uses both the ARCS motivation model and the IMMS modified from Keller to develop game-based instructional materials and determine if they effectively convey knowledge and raise motivation to learn about green building.

\section{Development and Design of the GBGame}

\subsection{Concept}

The GBGame presented in this research simulates building construction in plots zoned for different land uses within the framework of city development. Within a given budget, players can construct buildings using construction cards and function cards that allow various strategic actions and implement various green building technologies to achieve the ultimate goal of developing an ecologically sound city.

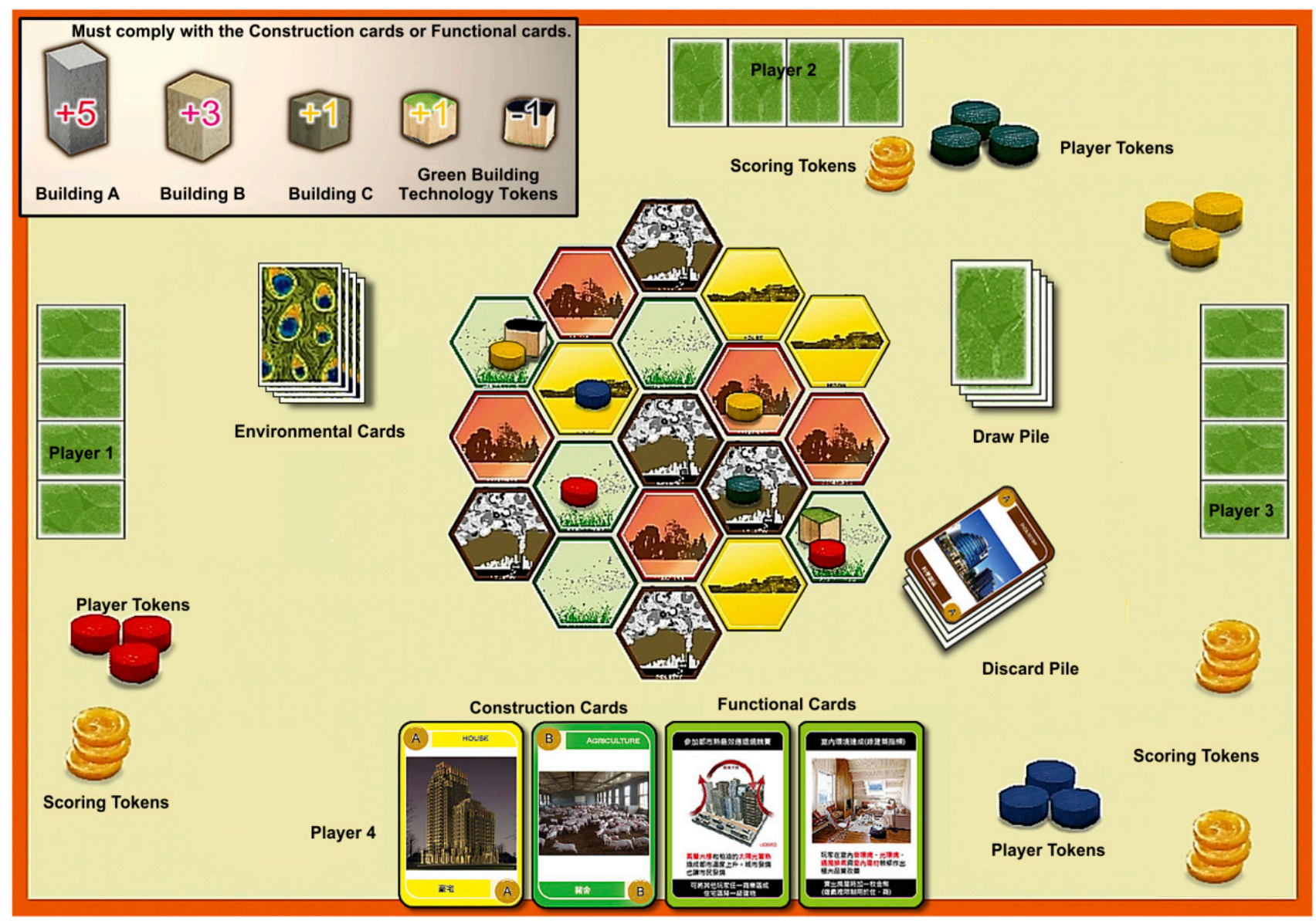

Figure 1. Schematic diagram of the game.

\subsection{Game Materials}

The physical aspects of the game (Figure 1) are comprised of base boards, cards, and tokens. The 19 hexagonal base boards simulate city plots dedicated to one of four land uses: commercial (red), 
industrial (coffee), residential (yellow), and agricultural (green). There are three types of cards: 72 construction, 32 function (including cards that spur interaction among the players as well as cards representing various green building technologies or strategies), and 35 environment. Tokens are divided into the following three types:

Player tokens: These are cylindrical markers representing the player's ownership of given lands; they are divided into five colors (to allow for five unique players), with four tokens for each color (one for each type of land use).

Building tokens: These are made up of three groups (Building A, B, and C) of 16 cubes each in three different colors and heights, representing building grades, which are upgradeable.

Green technology tokens: These are two-sided 20 green and black semicircular function markers. The green side represents green building technologies that have been applied in the buildings, whereas the black side represents punitive deductions for the lack of a green building concept.

\subsection{Sequence of the Game}

Figure 2 presents the steps of the game, which are as follows:

(1) Starting action: The base boards are placed randomly in a clockwise direction. Then, the construction cards and function cards are shuffled and dealt to every player, after which the players choose a color for the tokens that represent their roles and claim one board of each respective land type.

(2) Dealing environment cards: One environment card is dealt before the start of every round to simulate one of the ecological challenges faced by cities. For example, if a player extracts an environment card that reads "Environmental condition: global climate change has led to the worsening of urban heat island effects" and the player's building has either a "Water-permeable pavement" card or a "Green roof" card — either of which mitigates the heat island effect - the player is exempt from the negative effect and is awarded one scoring token.

(3) Routine actions: Players can select one action for execution each round; examples include purchasing land, constructing a building, and investing in green building technologies. After completing construction of a building, players can also decide whether to sell land. In addition, cards can be strategically traded for new cards from the draw pile.

(4) Special action: Players can interact with one another in various ways during the game process using the function cards. For example, a player may play a function card affecting another player, such as "Excessive CO emissions from building materials" or "Failure to meet waste reduction benchmarks." If the other player has not yet invested in green building technologies pertaining to these adverse developments, s/he pays the fine noted on the function card (reducing his/her score by one point) or is suspended for one round as punishment. In addition, function cards can be used to add value or defend against attacks by other players. For example, a player may be rewarded for using the "Water-saving technology" function card while defending an attack by another player's "Drought" function card. The aim is to encourage players to use as many function cards as possible for strategic purposes; in addition to being helpful in progressing the game, the use of these cards helps players to acquire more knowledge related to green buildings while playing. 
(5) Ending action: To prevent players from expanding their lands infinitely, the game ends when any player sells his/her fourth piece of land. However, this does not imply that that player has won the game; rather, each player's total number of gold coins is calculated (one point for each coin), with additional points awarded for various features (five additional points for each Grade A building, three additional points for each Grade B building, and one additional point for each Grade C building), and the total amount of green building technology rewards earned is calculated (one additional point for any one type of green building technology investment); deductions are also made (one point for each deduction token). The player with the highest final score wins the game.

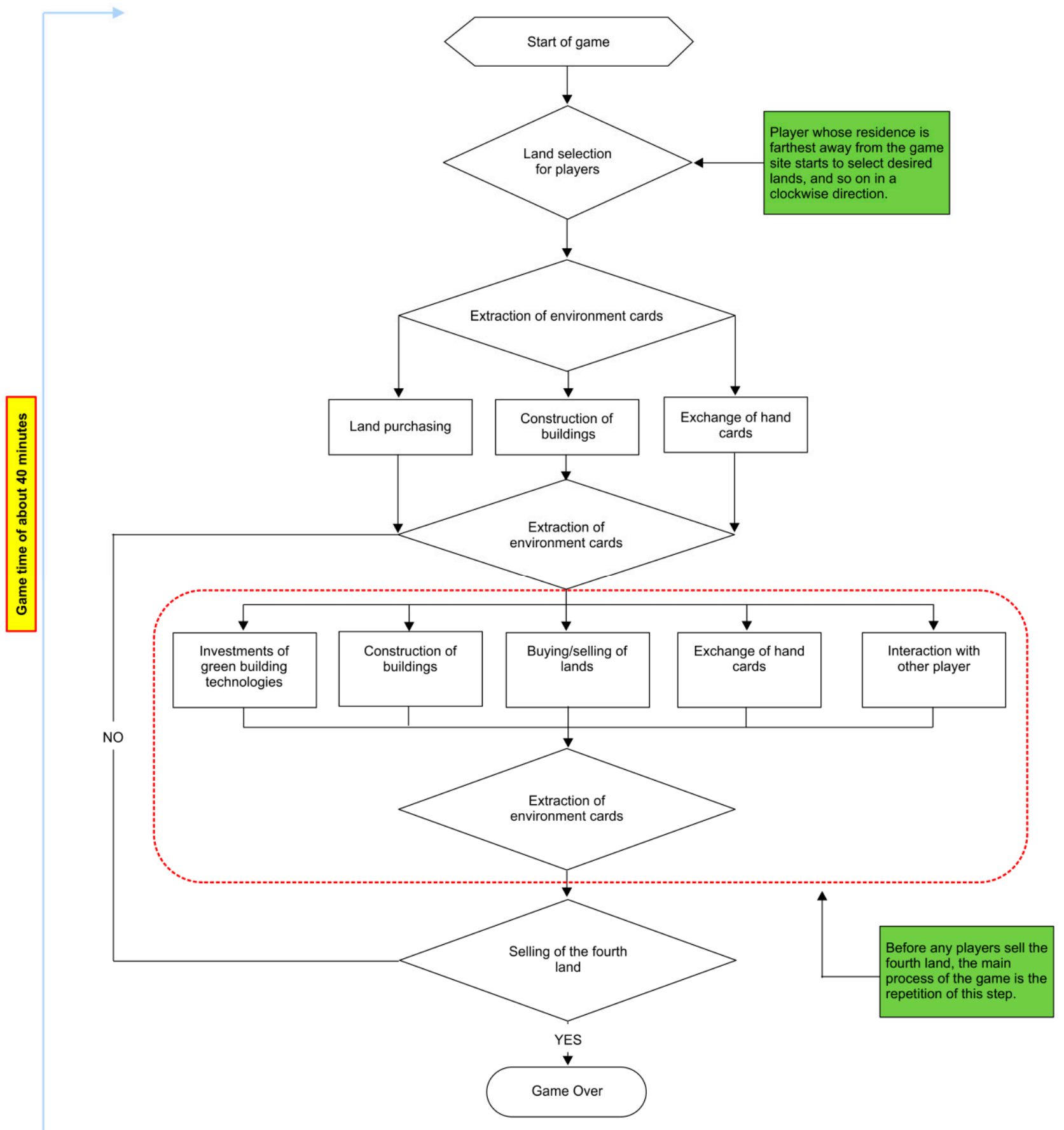

Figure 2. Flow diagram for game steps. 


\section{Description of the Experiment and Validation of the Game}

\subsection{Purpose of the Game Experiment}

This experiment has four main objectives: (1) to validate the learning motivation of experimental subjects using the ARCS motivation model and IMMS; (2) to identify any difference in the effectiveness of learning between the experimental group and the control group, the latter of which did not adopt game-based learning but rather engaged in paper-based examination of green building concepts following instruction; (3) to discuss the relationship between the ARCS motivation model and learning effect using the cross-validation method; and (4) to examine the dramatic attractiveness of the game system.

\subsection{Experimental Subjects}

The experimental subjects were 72 higher vocational school students majoring in architecture (average age of 17 years old), divided into two classes (A and B). The experiment was conducted over the course of one week during instruction of "Basic Concepts of Green Building" in an Introduction to Architecture course in June 2013. For this learning topic, participants formally received information about green buildings for the first time in their program. In class A, the control group, students were taught about green buildings for an hour and a half using a traditional lecture-based teaching method; class B (the experimental group), however, spent the same amount of time learning about green buildings using the GBGame. As shown in Figure 3, during the experiment, four players participated in each round of the GBGame (excluding the teaching assistants). Since the game content was developed based on the teaching materials used in the traditional class, students in both groups received similar information. Following the completion of the learning activity, students from both groups were immediately examined by having them complete a green building exam within a 45-minute time limit. They were also required to complete the IMMS related to traditional lecture-based and game-based learning.

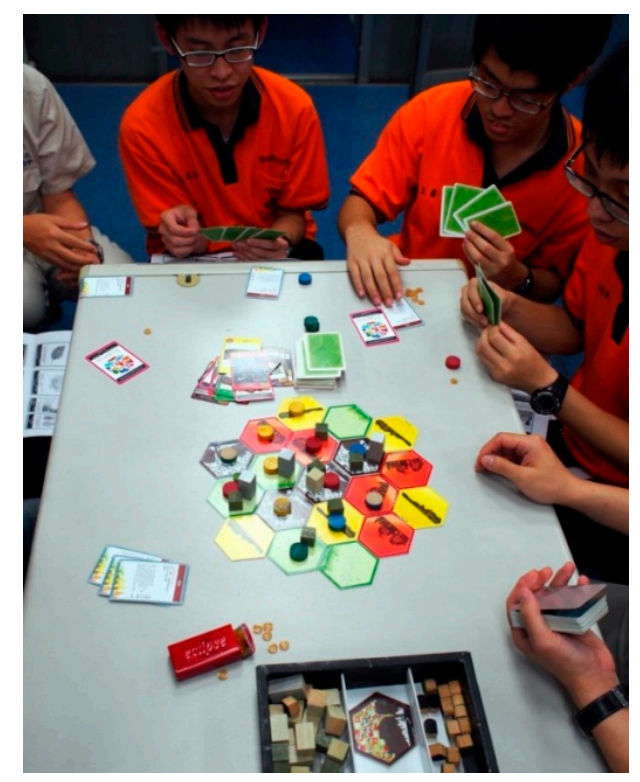

Figure 3. The experiment group for game play. 


\subsection{Research Tool}

The IMMS has been applied in many educational studies [40], and is often used to analyze learners' motivational level in relation to specific instructional materials [36]. Keller [43] examined the reliability of IMMS using Cronbach's $\alpha$, garnering a result of between 0.81 and 0.96 . Guilford [46] suggested that Cronbach's $\alpha$ greater than 0.7 indicates a considerably high reliability, while 0.35 to 0.7 indicates moderate reliability. The survey modified from Keller's IMMS in this study was a closed questionnaire consisting of 36 questions covering attention (A), relevance (R), confidence (C), and satisfaction (S). To avoid any confounding influences of boredom or fatigue on the part of the experimental subjects, the questionnaire items were scrambled.

To assess the learning effect of the game, a 20 multiple-choice question and two open-ended (calculation) question green building exam was used. These questions were developed based on the teaching materials, and it was ensured that students could acquire the right answers either directly or indirectly and through either traditional or game-based learning.

\section{Data Analysis and Results}

\subsection{Validation of the Learning Motivation Effect}

All students in class A and B returned instructional material motivation surveys; the survey items and students' results are shown in Table 1. The reliability, using Cronbach's $\alpha$, of the survey for the two groups was 0.891 and 0.911 , respectively. For the experimental group (who played the game), satisfaction items scored the highest among the ARCS $(M=4.25)$, followed by relevance $(M=4.16)$, indicating that the learners were satisfied with the game as a method of green building instruction and considered game-based learning capable of improving their attention and interest with regard to green building issues; moreover, they felt that the learning process gave them a sense of achievement. The situations simulated within the game also emphasized the personally relevant nature of such issues, and participants concluded that the game was both practical and entertaining. The results for the confidence items $(M=4.06)$ indicate the importance of clearly explaining the rules of the game; the learners considered the game to be moderately difficult. The players were confident that they were learning useful knowledge related to green building, and they felt that the effectiveness of learning could be improved with repeated play. The results for the attention items $(M=4.00)$ showed that the game stimulated learners' attention and interest and that the embedded environmental issues were worthy of attention.

For all four categories and most items, the average scores in the experimental group are 4 or greater, significantly higher than the scores in the control group who underwent lecture-based instruction. The result indicated that students had strong motivation to use this game to learn about green building $[47,48]$. 
Table 1. IMMS-based questionnaire for two groups.

\begin{tabular}{|c|c|c|c|c|c|}
\hline \multirow[t]{2}{*}{$\begin{array}{l}\text { ARCS } \\
\text { category }\end{array}$} & \multirow[t]{2}{*}{ Questionnaire items } & \multicolumn{2}{|c|}{$\begin{array}{c}\text { Class A: } \\
\text { traditional } \\
\text { lecture-based learning } \\
\text { (control group) } \\
\end{array}$} & \multicolumn{2}{|c|}{$\begin{array}{c}\text { Class B: } \\
\text { game-based learning } \\
\text { (experimental group) }\end{array}$} \\
\hline & & M. & S.D. & M. & S.D. \\
\hline \multirow{13}{*}{ Attention } & The material can attract my attention and interest from the start. & 3.69 & 0.75 & 3.83 & 0.68 \\
\hline & The material is capable of attracting people's attention. & 2.89 & 0.92 & 4.19 & 0.56 \\
\hline & The content of the material can attract my attention successfully. & 3.00 & 1.07 & 4.25 & 0.54 \\
\hline & $\begin{array}{l}\text { Elements in the material are so abstract that I cannot maintain my } \\
\text { focus. (reverse question) }\end{array}$ & 3.28 & 0.85 & 4.03 & 0.83 \\
\hline & The material is dull and unappealing. (reverse question) & 3.28 & 1.19 & 4.39 & 0.75 \\
\hline & The way the material is expressed can keep my attention. & 2.94 & 0.95 & 3.69 & 0.61 \\
\hline & $\begin{array}{l}\text { The material stimulates my curiosity about the planning and design } \\
\text { strategies of green buildings. }\end{array}$ & 3.47 & 0.91 & 3.81 & 0.65 \\
\hline & $\begin{array}{l}\text { Elements in the material are so repetitive that I feel bored. (reverse } \\
\text { question) }\end{array}$ & 3.17 & 0.88 & 3.97 & 0.92 \\
\hline & I can discover exciting and unexpected results from the material. & 2.86 & 1.25 & 3.47 & 0.72 \\
\hline & $\begin{array}{l}\text { The various experiences and learning I gathered from the material } \\
\text { held my attention. }\end{array}$ & 3.47 & 0.74 & 4.11 & 0.51 \\
\hline & The description of the material makes me bored. (reverse question) & 3.44 & 0.91 & 4.25 & 0.64 \\
\hline & The material includes many parts that are exciting to me. & 3.50 & 0.88 & 3.94 & 0.81 \\
\hline & Average of Attention & 3.25 & - & 4.00 & - \\
\hline \multirow{9}{*}{ Relevance } & I understand the content of the material. & 3.33 & 1.01 & 3.83 & 0.68 \\
\hline & $\begin{array}{l}\text { Conditions simulated in the material remind me that such } \\
\text { conditions or issues do exist in real cities. }\end{array}$ & 3.97 & 0.88 & 4.19 & 0.56 \\
\hline & $\begin{array}{l}\text { After studying (playing) the material, I have realized its } \\
\text { educational significance. }\end{array}$ & 3.69 & 0.82 & 4.25 & 0.54 \\
\hline & The content of the material does not interest me. (reverse question) & 3.64 & 0.96 & 4.03 & 0.83 \\
\hline & $\begin{array}{l}\text { Instructions are attached to the material to explain } \\
\text { how it is studied (played). }\end{array}$ & 2.58 & 0.73 & 4.39 & 0.75 \\
\hline & $\begin{array}{l}\text { The content and design of the material make me want to } \\
\text { understand it. }\end{array}$ & 2.97 & 0.91 & 3.69 & 0.61 \\
\hline & The material is not suitable for my knowledge level. & 2.42 & 1.00 & 3.81 & 0.65 \\
\hline & $\begin{array}{l}\text { I can find situations and incidents in my life that reflect those } \\
\text { presented in the material. }\end{array}$ & 3.69 & 0.92 & 3.97 & 0.92 \\
\hline & The content of the material is very practical to me. & 3.47 & 0.97 & 3.47 & 0.72 \\
\hline
\end{tabular}


Table 1. Cont.

\begin{tabular}{|c|c|c|c|c|c|}
\hline \multirow[t]{2}{*}{$\begin{array}{l}\text { ARCS } \\
\text { category }\end{array}$} & \multirow[t]{2}{*}{ Questionnaire items } & \multicolumn{2}{|c|}{$\begin{array}{c}\text { Class A: } \\
\text { traditional } \\
\text { lecture-based learning } \\
\text { (control group) } \\
\end{array}$} & \multicolumn{2}{|c|}{$\begin{array}{c}\text { Class B: } \\
\text { game-based learning } \\
\text { (experimental group) }\end{array}$} \\
\hline & & M. & S.D. & M. & S.D. \\
\hline & Average of Relevance & 3.31 & - & 4.16 & - \\
\hline \multirow{10}{*}{ Confidence } & $\begin{array}{l}\text { My impression is that the rules can be remembered easily after } \\
\text { the material is introduced, even for the first time. }\end{array}$ & 3.31 & 0.75 & 4.39 & 0.54 \\
\hline & $\begin{array}{l}\text { I consider many of the contents in the material to be } \\
\text { difficult for me. }\end{array}$ & 3.25 & 0.84 & 3.53 & 0.92 \\
\hline & $\begin{array}{l}\text { I have confidence that I can find ways to acquire green building } \\
\text { knowledge through the material. }\end{array}$ & 3.19 & 0.82 & 4.14 & 0.53 \\
\hline & There is too much material information for me to memorize. & 3.33 & 1.10 & 3.72 & 0.93 \\
\hline & $\begin{array}{l}\text { I have confidence that I can learn a lot of useful knowledge } \\
\text { from the material. }\end{array}$ & 3.25 & 0.84 & 4.17 & 0.55 \\
\hline & The material is difficult to study (play). & 3.44 & 1.23 & 4.42 & 0.68 \\
\hline & $\begin{array}{l}\text { I am more confident that I can achieve higher scores on the } \\
\text { subsequent test after repeated studies (plays) of the material. }\end{array}$ & 3.44 & 1.13 & 3.97 & 0.72 \\
\hline & $\begin{array}{l}\text { I do not understand the appeal of the material design. } \\
\text { (reverse question) }\end{array}$ & 3.00 & 0.89 & 4.06 & 0.62 \\
\hline & $\begin{array}{l}\text { The material has a good organizational structure and design; } \\
\text { thus, I am confident that I can master it. }\end{array}$ & 3.08 & 0.84 & 4.19 & 0.56 \\
\hline & Average of Confidence & 3.27 & - & 4.06 & - \\
\hline \multirow{7}{*}{ Satisfaction } & $\begin{array}{l}\text { I feel that I have a sense of achievement after the material is } \\
\text { studied (played). }\end{array}$ & 3.58 & 1.16 & 4.17 & 0.60 \\
\hline & $\begin{array}{l}\text { I am more interested in issues of green building because I am } \\
\text { fond of the material. }\end{array}$ & 3.28 & 0.88 & 3.92 & 0.64 \\
\hline & $\begin{array}{l}\text { I like the usage of the material as supplementary in courses of } \\
\text { green buildings. }\end{array}$ & 3.25 & 1.23 & 4.36 & 0.58 \\
\hline & $\begin{array}{l}\text { The teachers assist us during the study (play), making me feel } \\
\text { that it is meaningful when I participate in the study. }\end{array}$ & 3.58 & 0.84 & 4.22 & 0.53 \\
\hline & I feel happy because I can study (play) the material. & 3.28 & 0.88 & 4.42 & 0.59 \\
\hline & $\begin{array}{l}\text { I enjoy studying (playing) the material because of its } \\
\text { elaborate design. }\end{array}$ & 2.67 & 0.96 & 4.42 & 0.59 \\
\hline & Average of Satisfaction & 3.27 & - & 4.25 & - \\
\hline
\end{tabular}

\subsection{Validation of the Learning Effect}

The 45-minute green building exam was used as a tool to validate the learning effect (full score $=100$ ). Among the 72 exams distributed and returned, scores ranged from 35 to 95, with an average score of 77.61 for the experimental group, and 55.08 for the control group. By comparing the results of the two groups using a one-way ANOVA, it was discovered that the $p$-value $(p<0.0001)$ was significantly smaller than 0.05 , indicating that the learning effectiveness for students in the game-based learning group was significantly higher than for students in the traditional learning group. 
This result is consistent with the theory proposed by Keller [48] that the use of games in education can improve students' motivation and learning, while strategic games can further cultivate their problem-solving abilities; for example, the green building exam included two open-ended questions asking students to solve real-world green building challenges. Results indicate that the GBGame is an effective instructional material for the improvement of students' green building knowledge.

\subsection{Cross-Validation of Learning Motivation and Learning Effectiveness}

To establish a relationship between learning motivation and learning effectiveness, this study used regression analysis to cross-validate these results among the 36 experimental subjects, as shown in Table 2. The results indicate that the $p$-values are smaller than $0.0001(p<0.05)$. Therefore, there is a significant relationship between learning effectiveness and motivation, broken down into attention, relevance, confidence, and satisfaction. This positive correlation is aligned with findings by Keller and implies that if instructional materials and teaching models are attractive and meet the needs and desires of learners, and if appropriate content planning and guidance allow learners to gain a sense of achievement and satisfaction with the learning process, the learning effect will be significantly improved [16].

Table 2. Analysis of the relationships between attention, relevance, confidence, satisfaction, and learning effectiveness.

\begin{tabular}{cccc}
\hline Dependent variable & Independent variable & $\boldsymbol{R}^{\mathbf{2}}$ & $\boldsymbol{p}$-value \\
\hline & Attention & 0.710 & 0.000 \\
Learning effect & Relevance & 0.603 & 0.000 \\
(examination paper results) & Confidence & 0.654 & 0.000 \\
& Satisfaction & 0.563 & 0.000 \\
\hline
\end{tabular}

Note: Significance $<0.05$.

\subsection{Examination of Dramatic Attractiveness of the Game System}

To examine the dramatic attractiveness of the game, this study also developed a play-test mechanism wherein an additional four players repeatedly played six rounds of the game. For this play-test, A player was an experienced player and the other three players were beginners. The results, including players' scores and playing times of each round, are illustrated in Table 3. By using a one-way ANOVA and regression analysis, some interesting findings are further discussed below.

Table 3. Players' scores and playing time of each round.

\begin{tabular}{cccccc}
\hline $\begin{array}{c}\text { Game } \\
\text { rounds }\end{array}$ & $\begin{array}{c}\text { A Player's } \\
\text { scores }\end{array}$ & $\begin{array}{c}\text { B Player's } \\
\text { scores }\end{array}$ & $\begin{array}{c}\text { C Player's } \\
\text { scores }\end{array}$ & $\begin{array}{c}\text { D Player's } \\
\text { scores }\end{array}$ & $\begin{array}{c}\text { Playing time } \\
\text { (min) }\end{array}$ \\
\hline 1 & 14 & 7 & 11 & 8 & 32 \\
2 & 16 & 18 & 12 & 14 & 40 \\
3 & 17 & 12 & 13 & 10 & 43 \\
4 & 14 & 15 & 15 & 11 & 41 \\
5 & 14 & 16 & 11 & 15 & 46 \\
6 & 11 & 13 & 15 & 12 & 44 \\
\hline
\end{tabular}


First, the one-way ANOVA revealed that there was no significant difference between the scores of the A player and the scores of the other three players due to the $p$-value $(p=0.39)$, which was significantly higher than 0.05 . This result infers that players, with appropriate learning and involvement, can achieve equally high performance when playing the game no matter their level of familiarity or experience with the game. This examination also demonstrates the fairness and equilibrium of the game system design, wherein players do not feel anxious, frustrated, or bored during game play.

Second, this study used regression analysis to validate the relationship between the game rounds (independent variable) and the playing time (dependent variable). The results indicate that the $p$-value ( $p=0.04, R^{2}=0.69$ ) is smaller than 0.05 , showing the strong relationship between the two variables: the higher the number of game rounds, the longer the game playing time. This finding concludes that the game, to some degree, has its own complexity and variability that requires players, when they became more experienced, to spend more time involved and interacting with others to win the game. When the challenges continue, players' ability may gradually rise, and the game should be more attractive. This result was also supported by the concept of the flow theory proposed by Csíkszentmihályi [49], which states that players can be fully immersed in a feeling of energized focus, full involvement, and enjoyment in the process of game-playing.

Third, the scores of four players, as shown in Figure 4, can be depicted in different zigzag lines. The results of these lines were similar to Fullerton's [50] Dramatic Arc regarding game design, which proposes that a good game design should experience several stages: exposition, rising action, climax, falling action, and resolution. The game usually begins with exposition; after introducing conflicts, players produce a series of events that lead to increasing actions toward reaching the goal. These actions lead to a climax, in which some sort of deciding factor or event is introduced. The climax is followed by a period of falling action, in which conflicts begin to resolve, and, finally, the resolution. In this play-test, it can be further observed that each player can develop his/her own Dramatic Arc, which indicates that the game has achieved its capable depths, leading to recognition as an insightful and dramatic learning tool.

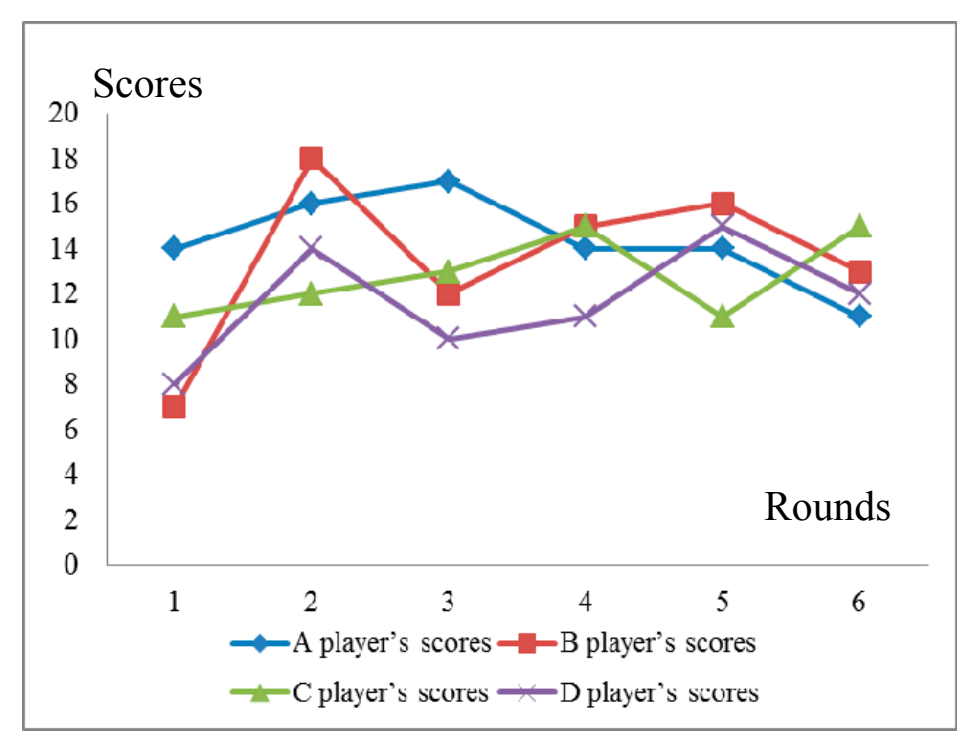

Figure 4. Players' game-playing arc. 


\section{Conclusions and Discussion}

As issues such as rapid environmental change and urbanization become increasingly important, various national governments are focusing on designing green building assessment systems that are in line with their own customs and culture. However, the promotion of green building has faced many obstacles, such as a lack of interest in engaging in greener building practices, stemming from widespread unawareness of its benefits. Given the identified advantages of games in education, this study designed and tested a strategic tabletop game to deliver green building knowledge, so that players could learn while playing and become motivated to learn how to improve the ecological friendliness of buildings in an urban environment.

This study used an ARCS motivation test and a green building exam to assess the effectiveness of green building education. The motivation results indicated that the experimental subjects exhibited strong learning motivation toward the game process, implying that the game was both practical and entertaining, and that it could stimulate players' attention and interest as well as help them to acquire useful knowledge relating to green building, thereby yielding a high degree of satisfaction. Correspondingly, the exam results indicated that the experimental group learned significantly more than the control group, implying that game-based learning was more effective than traditional learning for the same material. Through a cross-validation, this study also discovered that all four aspects of the ARCS motivation model are significantly related to learning effectiveness. This finding implies that if players can concentrate on the game while appropriate planning and guidance is provided, they can achieve a greater sense of satisfaction during the game process, greatly increasing learning effectiveness. In addition, the game system design demonstrates a high level of attractiveness, wherein players can be fully immersed in the process of game play. These conclusions may spur the development of innovative teaching models and instructional materials in the future.

Although the study presented here reveals that game-based green building education is a feasible and potentially successful teaching model, there are some limitations and challenges needed to be overcome; continuous improvements of the game system to reach the optimal equilibrium status considering instructional and recreational purposes are required. Some students, for example, reflected that the game should provide more interactive mechanisms among players to increase its excitement; moreover, refining the rules, procedures, and time control is necessary to promote and commercialize the game in the near future. Most importantly, the objective of this paper is not to impugn the effectiveness of traditional teaching methods or other techniques in a teacher's repertoire. Rather, this study suggests that games should be regarded as an effective teaching aid to enhance teaching practice, curriculum development, and the educational field as a whole. With the increasing ubiquity of consumer electronics, educational video games delivered via personal computer or smartphone are another promising way to deliver game-based education, including education in green building. In this way, the concepts of green building could be popularized more quickly and conveniently.

\section{Acknowledgments}

The authors are appreciative of the valuable comments from editors and anonymous reviewers. Their detailed comments helped to improve the clarity and focus of this paper. This study was 
funded by the Ministry of Science and Technology of Taiwan (R.O.C.) as Project No. 102-2511-S011-008-MY2. The authors were also grateful to the students who participated in the game experiment.

\section{Author Contributions}

Both authors contributed equally to this work. In particular, Yi-Kai Juan led the research activities and designed the game framework. Tseng-Wei Chao conducted the experiment, collected the data, and performed the analysis.

\section{Conflicts of Interest}

The authors declare no conflict of interest.

\section{References}

1. Ambrosini, D.; Galli, G.; Mancini, B.; Nardi, I.; Sfarra, S. Evaluating Mitigation Effects of Urban Heat Islands in a Historical Small Center with the ENVI-Met ${ }^{\circledR}$ Climate Model. Sustainability 2014, 6, 7013-7029.

2. Li, F.; Wang, R.; Paulussen, J.; Liu, X. Comprehensive concept planning of urban greening based on ecological principles: A case study in Beijing. Landsc. Urban Plan. 2005, 72, 325-336.

3. Nordbo, A.; Järvi, L.; Haapanala, S.; Wood, C.R.; Vesala, T. Fraction of natural area as main predictor of net $\mathrm{CO}_{2}$ emissions from cities. Geophys. Res. Lett. 2012, doi:10.1029/2012GL053087.

4. Wang, S.; Yan, C.; Xiao, F. Quantitative energy performance assessment methods for existing buildings. Energ. Build. 2012, 55, 873-888.

5. Han, J.H.; Kim, S.S. Architectural Professionals' Needs and Preferences for Sustainable Building Guidelines in Korea. Sustainability 2014, 6, 8379-8397.

6. Tam, V.W.Y.; Hao, J.L.; Zeng, S.X. What affects implementation of green buildings? An empirical study in Hong Kong. Int. J. Strateg. Prop. Manag. 2012, 16, 115-125.

7. Cole, R.J. Emerging trends in building environmental assessment methods. Build. Res. Inf. 1998, 26, 3-16.

8. Ding, G.K. Sustainable construction: The role of environmental assessment tools. J. Environ. Manag. 2008, 86, 451-464.

9. Shi, Q. Strategies of implementing a green building assessment system in Mainland China. J. Sustain. Dev. 2008, 1, 13-16.

10. Mao, X.; Lu, H.; Li, Q. A comparison study of mainstream sustainable/green building rating tools in the world. In Proceedings of the International Conference on Management and Service Science, Wuhan, China, 20-22 September 2009; IEEE: Piscataway, NY, USA; pp. 1-5.

11. Cole, R.J. Building environmental assessment: Changing the culture of practice. Build. Res. Inf. 2006, 34, 303-307.

12. GBI Research Reports. Green Buildings Market to 2015-Incentives for Green Initiatives and Minimum Level of Standards to Boost Growth Opportunities; Alacra Store: New York, NY, USA, 2010. 
13. Chang, K.F.; Chiang, C.M.; Chou, P.C. Adapting aspects of GBTool 2005-Searching for suitability in Taiwan. Build. Environ. 2007, 42, 310-316.

14. Ho, M.C. Development of the intelligent green building in Taiwan. Available online: http://2013twfr.weebly.com/uploads/1/8/5/2/18521992/_2-2.pdf (accessed on 29 April 2015).

15. Williams, K.; Dair, C. A framework for assessing the sustainability of brownfield developments. J. Environ. Plan. Manag. 2007, 50, 23-40.

16. Reinhart, C.F.; Dogan, T.; Ibarra, D.; Samuelson, H.W. Learning by playing-teaching energy simulation as a game. J. Build. Perform. Simul. 2012, 5, 359-368.

17. Zhai, X.Q.; Wang, R.Z.; Dai, Y.J.; Wu, J.Y.; Ma, Q. Experience on integration of solar thermal technologies with green buildings. Renew. Energ. 2008, 33, 1904-1910.

18. Pan, Y.; Yin, R.; Huang, Z. Energy modeling of two office buildings with data center for green building design. Energy Build. 2008, 40, 1145-1152.

19. Yao, J. A Multi-Objective (Energy, Economic and Environmental Performance) Life Cycle Analysis for Better Building Design. Sustainability 2014, 6, 602-614.

20. Chau, C.K.; Tse, M.S.; Chung, K.Y. A choice experiment to estimate the effect of green experience on preferences and willingness-to-pay for green building attributes. Build. Environ. 2010, 45, 2553-2561.

21. Dammann, S.; Elle, M. Environmental indictors: Establishing a common language for green building. Build. Res. Inf. 2006, 34, 387-404.

22. Retzlaff, E.C. Green building assessment systems: A framework and comparison for planners. Build. Res. Inf. 2008, 74, 505-519.

23. Berardi, U. Stakeholders' influence on the adoption of energy-saving technologies in Italian homes. Energ. Policy 2013, 60, 520-530.

24. Li, Y.; Yang, L.; He, B.; Zhao, D. Green building in China: Needs great promotion. Sustain. Cities Soc. 2014, 11, 1-6.

25. Perng, Y.H.; Juan, Y.K.; Chien, S.F. Exploring the bidding situation for economically most advantageous tender projects using a bidding game. J. Construct. Eng. Manag. 2006, 132, 1037-1042.

26. Poplin, A. Playful public participation in urban planning: A case study for online serious games. Comput. Environ. Urban Syst. 2012, 36, 195-206.

27. Torres, M.; Macedo, J. Learning sustainable development with a new simulation game. Simul. Gaming 2000, 31, 119-126.

28. Rieber, L.P. Seriously considering play: Designing interactive learning environments based on the blending of microworlds, simulations, and games. Educ. Technol. Res. Dev. 1996, 44, 43-58.

29. Rosas, R.; Nussbaum, M.; Cumsille, P.; Marianov, V.; Correa, M.; Floresa, P.; Salinasa, M. Beyond Nintendo: Design and assessment of educational video games for first and second grade students. Comput. Educ. 2003, 40, 71-94.

30. Parlett, D. Oxford History of Board Games; Oxford University Press: Oxford, UK, 1999.

31. Eisenack, K. A climate change board game for interdisciplinary communication and education. Simul. Gaming 2012, 44, 328-348.

32. Scott, D.; Cullingford, G. Scheduling game for construction industry training. J. Construct. Div. 1973, 99, 81-92. 
33. GEOlino Meltdown. Available online: Meltdown-game.com (accessed on 15 December 2013).

34. Arslan, H.O.; Moseley, C.; Cigdemoglu, C. Taking attention on environmental issues by an attractive educational game: Enviropoly. Procedia-Soc. Behav. Sci. 2011, 28, 801-806.

35. Zhang, $\mathrm{X}$. The combination of traditional teaching method and problem-based learning. China Pap. 2002, 1, 30-36.

36. Rodgers, D.L.; Withrow-Thorton, B.J. The effect of instructional media on learner motivation. Int. J. Instr. Media 2005, 32, 333-340.

37. Jeamu, L.; Kim, Y.; Lee, Y. A web-based program to motivate underachievers learning number sense. Int. J. Instr. Media 2008, 35, 185-194.

38. Keller, J.M. Instructional Design Theories and Models: An Overview of Their Current Status; Reigeluth, C.M., Ed.; Lawrence Erlbaum: Hillsdale, NJ, USA, 1983; pp. 384-434.

39. McKeachie, W.J.; Svinicki, M. McKeachie's Teaching Tips: Strategies, Research, and Theory for College and University Teachers, 12th ed.; Houghton-Mifflin: Boston, MA, USA, 2006; pp. 140-150.

40. Green, M.; Sulbaran, T. Motivation assessment instrument for virtual reality scheduling simulator. In Proceedings of the World Conference on E-learning in Corporate, Government, Healthcare, and Higher Education, Honolulu, HI, USA, 13-17 October 2006; Association for the Advancement of Computing in Education: Chesapeake, VA, USA; pp. 45-50.

41. Luterbach, K.J.; Reigeluth, C.M. School's not out, yet. Educ. Tech. 1994, 34, 47-54.

42. Frymier, A.B.; Shulman, G.M. "What's in it for me?" Increasing content relevance to enhance students' motivation. Commun. Educ. 1995, 44, 40-50.

43. Keller, J.M. Motivational Design for Learning and Performance: The ARCS Model Approach; Springer: New York, NY, USA, 2010.

44. Small, R.V.; Gluck, M. The relationship of motivational conditions to effective instruction. Educ. Technol. 1994, 36, 33-40.

45. Keller, J.M. IMMS: Instructional Materials Motivation Survey; Florida State University: Tallahassee, FL, USA, 1987.

46. Guilford, J.P. Fundamental Statistics in Psychology and Education, 4th ed.; McGraw-Hill: New York, NY, USA, 1973.

47. Bolliger, D.U.; Supanakorn, S.; Boggs, C. Impact of podcasting on student motivation in the online learning environment. Comput. Educ. 2010, 55, 714-722.

48. Garris, R.; Ahlers, R.; Driskell, J. Games, motivation, and learning: A research and practice model. Simul. Gaming 2002, 33, 441-467.

49. Csíkszentmihályi, M. Flow: The Psychology of Optimal Experience; Harper and Row: New York, NY, USA, 1990.

50. Fullerton, T. Game Design Workshop: A Playcentric Approach to Creating Innovative Games, 2nd ed.; Morgan Kaufmann: Burlington, MA, USA, 2008.

(C) 2015 by the authors; licensee MDPI, Basel, Switzerland. This article is an open access article distributed under the terms and conditions of the Creative Commons Attribution license (http://creativecommons.org/licenses/by/4.0/). 